\title{
Implications behind the Covid 19: A Profound Structural Change Out Of Catastrophy?
}

\author{
Ferdi T. Güçyetmez ${ }^{1}$, Javaid Ahmad Andrabi ${ }^{2}$, Muhammad Ridwan ${ }^{3}$ \\ ${ }^{1}$ Faculty Of Humanities And Social Sciences, İstanbul Kent University. He continue the academic \\ studies in Switzerland \\ ${ }^{2}$ Department of Geography, Govt. Degree College pampore , Jammu and Kashmir , India \\ ${ }^{3}$ Universitas Islam Negeri Sumatera Utara, Indonesia \\ Email: ferdigucyetmez26@gmail.com, andrabijavaidahmad@yahoo.com, bukharyahmedal@gmail.com
}

\begin{abstract}
:
Robert Cox has been the most well-known, and prominent intellectual as well, by articulating the building process of historical bloc within the context of the emergence of social forces initially in the nation-state, and his attempt has culminated in the unquestionable power of transnational power in global political economy for those who has vested interest in the identity of hegemony. By the article, we present a tentative attempt in effect by such a hypothetical assumption that the power configurations of social forces, state and world order fell default in their challenge against the unprecedented Virus pandemic while the virus itself has no such configurations as material capability, idea and institutions. The Covid 19 set up its own hegemony literally. The global politics has always been exposed to independent variables not predicted even though collectively or individually measures are taken by states. In this study, we will talk about the emergence of a new hegemonic power with the Covid 19 Pandemic.
\end{abstract}

Keywords:

Covid 19; Coxian theory; new world system; gramschi

\section{Introduction}

Countries take some level of measures to advance the progress of states and protect their territorial integrity. These measures could have been considered with the focus of military defence until now. However, the century we are in has shown us that military defence and expenditures alone are insufficient. The steps taken by the rising sovereign powers compared to other countries are significant for the new order, because technology, science, education, economy and sociology require a complete integration in the new world order. While the military defence was at the top of this list in ancient times, it had to leave its place to technology and research spending. At the time when this whole order changed, a global event accelerated this change: Covid 19.

The unevenness of countries around the world and the formation of a unipolar order deeply affected the fate of history and the world. The first disorder of the new order, which started to emerge after Westphalia, started to affect the global equation again with long wars. While trying to establish a balance of power on its own axis, Europe entered the race to exploit the countries of the world. Western countries, which wanted to establish power hegemony despite their mutual dependence on each other, would realize that this futile order would be fruitless only when they started the world wars. Theorists used to say that wars had to take place in order for these irregularities to come into order. The more important wars brought by the exploitative races caused more loss and destruction rather than order. It took an average of a thousand years for European states, hurrying from one war to another, to realize that order cannot come through war. At this point, institutions and countries that became dependent on each other thanks to these institutions emerged. It was at this point that 
we, as international relations workers, had to make new tasks and definitions. This is a mutual dependence and mutual independence.

In the literature of pluralist international relations, interdependence refers to the conditions shaped by the interaction between countries in world politics or between actors in different countries. So interdependence; It is the complex set of conditions created by the connections and relationships created by the many channels of interaction between states and societies in an international system that lacks a definite hierarchical agenda (Keohane \& Nye, 2011; 7).

While European countries were at war, they actually lost the hegemony they were fighting for another country; The United States. It had reached such a size in the war environment that America had become a world centre on its own. Huntington (1994; 22-49), Kissinger (1994) and Brzezinski (1997) acknowledged this uneven growth of America and reported them in their work. Changes in the international system have pushed the system to re-explain and form a basis. These foundations started to be redesigned with the Cold War. The interdependence paradigm that Keohane and Nye (1998) brought to the literature together with the Power and Interdependence theory put forward towards the end of the Cold War period, differentiated and transformed with the effect of the obvious changes in the system in the following period. The factors that emerged with the power hegemony put forward later were replaced by different rules. Especially, the transnational operations and the hard power element that emerged after the September 11 attack have been replaced by wars of regional hegemony. After the end of the cold war and the September 11 attacks, the world has entered a new order. After this process, it has gained a new dimension with a new global event today, where smart power and soft power elements continue. Yes, the Covid 19 pandemic has made us question this entire global system again.

\section{Review of Literature}

When we reconsider, we think we are in a period where states need to change their arguments systematically. In this period, when the use of force changes method, the theory of mutual dependency and hegemony works fully. In this period, when countries try to put pressure on economic and health management, the force has reached a different dimension. The reconsideration and evaluation of the wars of hegemony with Covid 19 pass through the redefinition of the world that has entered the global crisis. In this study, we will try to deal with the principles of hegemony and interdependence with a realistic theory, and we will try to process this period in which countries put pressure on each other again.

\subsection{The Covid 19; A Scape Goat?}

Coxian reading on the current pandemic disease in terms of international relation has been made to account for the prospective counter-hegemonic historical structure. Nevertheless, since no single theory could be adequate to figure out any single event in global matters, neo Gramscian approach alone will fall short to figure out the new modes of social relations giving impetus for the emergence of social forces considering the contemporary developments in global politics. No matter where it began, the Covid 19 virus has been penetrating, infiltrating and proliferating without recognizing any political obstruction imposed by any agent at all for security purpose. Is it wrong to make such a claim that this pandemic itself is in effect the hegemon against which no material capability, idea or institution could put forward any challenge against it? Or from the vice versa approach, this pandemic disease without idea, material capability or institutions became the stimulus for each 
sovereign to change its behavior immediately, or sooner rather than later. While spreading in and out, the social force is solely Covid 19 itself urging states to behave the same way; protection and survival as the ultimate end in defensive manner in the self-help world.

What it produced is just a dark future due to uncertainty for humanity. No one could give any tangible assurance for future behavior (Thompson, 1983). "Moreover, states were caught unprepared for such unexpected outbreak of disease as the world in economic and political realm had already been suffering from recession, conflict of interest and stagnation" (Bertalanffy, 1972; 407-426). No doubt, the pandemic disease particularly contributed into the fear for all consumers as well. Even though the social distance is accepted as the most rational means for personal protection against the infection, people has already been locked into the virtual reality by wasting the crucial and vital share of their daily life on internet-access requiring technological productions (Hopkins; 1982).

Considering the shortage of money in circulation resulting in increase in the value of money, price of goods will eventually decrease to eliminate the excess supply that is simply due to decreasing demand. "Fear of uncertain future among consumers make them keep their cash as saving rather than spending" (Doran, 1989; 44). Soft currency states also have been suffering from depreciation of their currency in relative to internationally strengthening hard currency (US Dollar). Budget deficit and trade deficit made it almost impossible for the developing countries to achieve in sustaining debt management in brief. For developing countries, apart from defense spending, revenue from tourism dramatically drops each passing period. They all found themselves in race to find money that could not be issued by their Central Banks. Considering Covid 19 in the world of interdependence, the system will experience domino effect without doubt under the pressure of deflation. Failing to increase demand for good will eventually lead to increase in unemployment since companies will begin to cut their cost by laying off their workers. "Exchange rate of local currencies of developing states keep depreciating against the Dollar (USD) due to excess demand by them" (Hall, 1993). The deteriorating credibility of macroeconomic power of developing states also contributes to the consolidation of the USD. To sustain budget deficit, while it is hard to find USD, it became the way as a last resort to use reserves in dollar in particular apart from other means like swaps via public banks, and the central banks as well, to increase their constantly narrowing maneuvering space for open market operations (OMO) by the Central Banks. Due to volatility in exchange rate at the expense of the soft currency, we observe inflation not because of excess demand for good, but of the cost of production. "Not the inflation but the depreciation of currency leads to inflation, as from the cost of intermediate goods to the cost of inputs begins to increase regarding soaring price level of imported crude oil and natural gas" (Dougherty, 1979; 45), which in return results in increase in interest rates. Tightened monetary policy (increasing interest rates) is to decrease the money supply to place control on inflation. As can be seen, cause and effect should not be confused just for political reasons. The inflation in Turkey is decreasing due to simply dramatic decrease in demand. This is the deflation. The cost will eventually be unemployment in a simple account. At final account, fluctuations in the exchange rate have always been the prominent controversial issue even among economists, but credibility of ruling powers are being questioned more and more profoundly by civil power who has been passing through in pain unprecedented pandemic crisis.

In Turkey, shopping centers (Shopping Malls) have been the output of changed patterns of social relations of production. However, recent years proved that online shopping began to replace the previous currency, extensive construction of shopping centers one after another, in terms of changing shopping habits among Turkish consumers. Fear of being infected by Covid 19 contributed to the change the way of demand and consumptions all over 
the world. "While shopping centers began to save themselves from the cost of rent and even tax burden, apart from labor cost, to some extent, delivery services emerged to take advantage of new patterns of production"( Frank \& Gills, 1993).

We briefly observe new social forces to meet the new demand. Social networking services like twitter, Facebook, Instagram turned out to be the cheapest way of propaganda machine for political parties. Blockchain, deep and dark web, crypto currency (bitcoin) and cyber security are all the lightspeed technological innovations to redefine social patterns of relations or knowledge. During the pandemic period, people began to learn how to adjust themselves to their new working conditions at home via internet.

The reason for such a brief account is to exhibit the circumstances already existing before the Covid 19. It is irrational to represent it as the scape goat. Rather than regarding the Covid 19 as the sole source of the conviction that nothing will be the same, the article emboldens the idea that the course of life has already changed before its outbreak to be frankly. Since the unit of analyses of the article is the state, the article on purpose keeps itself away from such ongoing discussions which have to do with domestic political developments either in political or economic terms. Since the source of hegemony and construction of historical bloc by which social forces gives as a form to the state, Coxian understanding initially indicates by emphasizing on transformative struggle within nation. Before moving outward, the article attempts to make explicit expression that Covid 19 ought not to be linked exclusively to the emergence of social forces similar in kind with the western social forces which was given birth after political and economic revolution as the mode of production changed. Upon these assumptions to confine the discussion within international arena as already attempted by Cox himself who was in search of how to apply Gramscian conceptualization on hegemony upon international arena, the hypothetical assumption based on the conviction that the material capability, idea and institutions as the power configurations of the historical block for its each segment which are social forces, forms of state and world order will fall short to challenge pandemic disease. "Changing patterns of production relations lead to the emergence of social forces which eventually turns out to be the bases of power initially in the nation and ultimately across states to set up a new world order, having given hegemonic form to the state from which they emerged" (Holsti, 1978; 145). However, what gave stimulus to the emergence of historical hegemonic block, as articulated by Cox, has failed to challenge such an unprecedented pandemic disease.

It is the virus completely destroying the components constituting historical bloc of hegemony. Not just the social forces to be taken as transnational forces, but also peripheral states have been under never-before experienced pressure in political and economic terms. Let it be clearer why Coxian approach will be weak in making elaborations on the recent developments in international affairs by discarding other independent variables such as global recession before the Covid 19, regional affairs like all around the world, the rise of Chinese power and trade war between the USA and China and so on and so forth. Even though by means of Coxian reading in detail, we can figure out to some significant degree how changing mode of production and patterns of production relations gave impetus to the rise of some social forces, they are long away from conducting counter historical block to make their state hegemon by exploiting opportunity out of catastrophe called the Covid 19. Even the social (transnational) forces who made the United States hegemon of western historical block has so far failed to stop the pandemic disease. Let aside the fear, it will be overgeneralization to make such an assumption that Covid 19 that produced a profound catastrophe is strong enough by itself to produce transformative revolution and struggle for a structural change, out of which social forces emerges, in global political economic order. 


\subsection{Neo Gramscian Ontology and Epistemology}

Robert Cox in accordance with Gramscian argument ontologically does not take for granted a static theory of politics as the mainstream theory of neorealist international relations. Wendt perfectly titled by detailing intersubjective meaning his conceptualization of anarchy; "Anarchy is what states make of it." Upon transformative struggle, change becomes inevitable. However, Cox explicitly provide us the point that such struggle and change should not be taken exclusively in materialistic terms, but historical dialectic. He, like other critical theorists, attempts to build on his ontological definitions his prominent groundbreaking epistemological reasoning by asking how struggle leads to change and gives a new meaning to the so-called knowledge. Put simply, Morton highlights Coxian focus by driving our attention on the puzzle that "what and how forces may have the emancipatory potential to change or transform the prevailing order" (Cox, 1981; 129).

Changing production relations as a consequence of political and economic revolutions result in the emergence of particular social forces. These social forces gradually give hegemonic form to the state. In order to sustain their power, social forces together with their hegemonic state move beyond the state. Thus, a world hegemony is in a simple framework "an outward expansion of the internal hegemony founded by a dominant class" (Cox, 1983; 171). Social forces ultimately become transnational force by completing internationalization of the state on economic scale. Production processes are maintained in different states as can bee seen by post Ford production system. As indicated by Cox, "international production expands through direct investment" (Cox, 1981).

\section{Discussion}

\subsection{No Longer Statist Hegemony?}

At final account, at least for now, the globalization, in tandem with variety of distinct conceptualizations of the Coxian conviction, reached to the global capitalism in which we observe transnationalization of hegemony. By the outbreak of Covid 19, hegemon states, all of which got entangled within the western hegemonic historical bloc, have been passing through a default while struggling to end the Coronavirus pandemic. No material capability, idea or institutions has so far managed to challenge against such an unprecedented pandemic at all.

It was not until the late 2020 when the Covid 19 was proclaimed to be the pandemic that Robert Cox's assumptions would be regarded appropriate to acknowledge the conviction that "states have been captured by transnationally oriented dominant groups who use them to integrate their countries into emergent global capitalist structures. "The globalization of production and the extensive and intensive enlargement of capitalism in recent decades constitute the material basis for the process of transnational class formation" (Robinson; 1996; 563). Robinson attempts to "call for expunging nation-state centrism from the discussion of hegemony" (Gramsci, 1976). Covid 19 and in particular its effect on global world cannot be efficiently analyzed by state-centric or nation-state-centric approaches since TCC (Transnational capitalist Class) cannot be located within any state.

Trade war between China and the U.S.A. justified that the world politics turned back to a sui generis new version of Cold War, which is somewhat similar to bipolar world system. We witness arbitrary wield of power by the U.S. through its material capability, not based on pure consent but coercion. Institutions have always been the means to legitimize its political practice by discarding demands from the subordinate states for a fair solution to any matters in global politics. However, the recent catastrophe called Covid 19 virus pandemic proved that 
the U.S is unable to confront such a challenge whatsoever. It will be underestimation of such a serious worldwide intimidation for all humanity by confining the pandemic to the containment of the Trump administration. However, it is not a complete unreasonable account to think that its motto "to make America great again" is a behind-the-curtain clash of interest with the transnational capitalist class. Then, let's think over whether it is really the matter of conflict in between China and the United States in the pretext of territorially-bounded rivals for hegemony? Robinson claims that globalization should be taken for granted in such a way that "it is not a 'national' project but a class project without a national strategy, or rather, with a strategy that seeks to utilize the existing political infrastructure of the nation-state system" (Robinson, 1996; 569).

Furthermore, the true beneficiaries of military intervention by the US are TCC via TNS and the US has always become the epicenter of transnational capitalist interest. Rather identifying the conflict between China and the US as an inter-sate conflict, we can confine the source of clash of interest to the White House where the Trump administration has been in quest of intimidating the means by which the US preserved its hegemony all over the world. What is puzzling is the prioritization of order and asking which comes first with regards to legitimacy; state or social force (read transnational force). State has the ontological priority for the penetration of transnational capital and integration of the intervened region into the global system. Who needs whom to accomplish the ultimate end (supremacy) is actually the intricated problem. From this point of view, Trump has been engaged in power struggle against who gave the United States hegemonic form. America during the Trump administration is at war with itself.

At this point, we need to take a closer look at the transformations of global systems (Modelski, 1983). Whether the new system, which we examine together with hegemony, strengthens the hegemonic powers more or takes them back is a new field that needs to be examined. In this section, we will try to look for answers by dwelling on this system.

\section{Conclusion}

Dispersed state power urged sovereigns to reconsider over and over after each catastrophic global event transcending beyond political borders to cope with the imminent cost of prospective structural change in global politics. Considering the last five decades of international political economic system, since the collapse of the Bretton Woods System (1944) as the Nixon Administration declared in August 1971 the end of the convertibility of the US Dollar into gold, we observe the complex interdependence-driven globalization in brief. The September 11 event propelled the United States to redefine the parameters, and dynamics within them, of its foreign policy. While those to be considered as policy-makers got engaged with such trans-border issues as crypto currency, cyber security, global warming, the world did get into the unprecedented deadlock as the Covid 19 became the name for the contemporary pandemic disease. Similar epidemic case broke out in the past, but the world, if compared with it, has never been interconnected in economic and politic realms at all. Coxian approach is taken for granted as a theoretical framework to some important extent to account for the current developments during the pandemic period by holding the state as the primary rational actor in this anarchic international system. Without doubt, the world has been passing through a new mode of social relations of production. Covid 19 has steadily been providing a sui generis dimension justifying that "national governments have lost much autonomy in policymaking, but also how states are still an integral part of this process" 
Since the establishment of World Health Organization in 1948, it itself has never been forced to confront such a challenge which ushered a new era for sovereigns with regards to getting involved in the competition in rival sense to discover vaccine to cure the pandemic disease called Covid 19. Not exclusively hegemony based on consent from within state and moving outward as articulated by Neo-Gramsci school, but sphere of influence became primary objective for sovereigns. Deteriorating macroeconomic indices of developing states during the pandemic disease made them vulnerable, exposed, and demand for financial support from either major powers like the U.S.A. and China, or international institutions like IMF. In the context of change within the mode of production, the article attempts to delineate by delving into the exploitative character of social relations through benefiting from the Coxian understanding.

\section{References}

Bertalanffy L. V. (1972). The History and Status of General Systems Theory. The Academy of Management Journal, 15 (4), pp. 407-426.

Brzezinski Z. (1997). The Grand Chessboard; American Primacy and its Geostrategic Imperatives, New York; Basic Books.

Cox R. W. (1981). Social Forces, Statesand World Orders; Beyond International Relations Theory, Millennium; Journal ofInternational Studies, 10 (2), pp. 126-155.

Cox R. W. (1989). Middle power manship, Japanand Future World Order, International Journal, (44) 4, pp. 823-862.

Doran C. F. (1983). Power Cycle Theory and the Contemporary State System. Contending Approaches to World System Analysis. California; Sage Publication.

Dougherty J. E. (1976). The Study of Global System. Michigan; Free Press.

Gramsci A. (1978). Selections From the Prison Notebooks of Antonio Gramsci, Quentin Hoare (der.), çev. G.Nowell Smith, NewYork: International Publishers.

Frank A. G. \& Gills, B. K. (1993). The 5,000-Year World System; An Interdisiplinary Introduction. London; Routledge Press.

Hall T. (1999). World-Systems and Evolution; An Appraisal New Directions in WorldSystems Research. Maryland; Rowman \& Littlefield Publishers.

Holsti K. J. (1978). A New International Politics? Diplomacy in Complex Interdependence. International Organization , 32 (2), p. 521.

Hopkins T. (1982). World-Systems Analysis Methodological Issues". California; SAGE Publications.

Huntington S. (1993). “The Clash of Civilizations?”, Foreign Affairs, Vol. 72, No. 3, p. 22-49.

Keohane R. O. (2002). Power and Governance in A Partially Globalized World. New York; Routledge.

Keohane O.R. ve Nye,J.S. (2001). Power and Interdependence, 3. published, New York; Addison Wesley Longman, p. 7.

Kissinger H. (1994). Diplomacy, New York; Simon\&Schuster Paperbacks.

Krasner S. D. (1983). Regimes and the Limits of Realism; Regimes as Autonomous Variables. New York; Cornell University Press.

Kroll J. A. (1993). The Complexity of Interdependence. International Studies Quarterly , 37 (3), pp. 322-323.

Modelski G. (1983). Long Cycles of World Leadership. California; SAGE Publications.

Modelski G. (1987). Long Cycles in World Politics. London; Macmillan Press.

Modelski G. (2000). World System History; The Social Science of Long-Term Change. London; Routledge Press. 
Modelski G., \& Thompson, W. (1993). "The Long and the Short of Global Politics in the Twenty-First Century; An Evolutionary Approach" International Studies Review , 2 (1), pp. 109-140.

Robinson W.I. (1996). Promoting Polyarchy; Globalization,US Intervention and Hegemony, Cambridge; Cambridge University Press.

Thompson W. R. (1983). World System Analysis With and Without the Hypen. California ; SAGE Publication.

Wallerstein I. (2011). The Modern World System I Capitalist Agriculture And the Origins of the European World-Economy in the Sixteenth Century. California; University of California Press. 